\title{
IMPLEMENTASI PERLINDUNGAN HUKUM TERHADAP KORBAN PENGANIAYAAN DALAM PENANGANAN TINDAK PIDANA DI KOTA TIDORE KEPULAUAN
}

\author{
Oleh : \\ Hasmiah Hamid
}

\begin{abstract}
ABSTRAK
Perlindungan hukum terhadap hak-hak korban penganiayaan yang dirasakan saat ini masih minim padahal masalah keadilan tidak hanya berlaku terhadap pelaku penganiayaan saja akan tetapi juga korban penganiayaan. Hal ini terjadi karena eksistensi dan posisi hukum korban tindak pidana dalam sistem peradilan pidana hanya sebagai saksi (pelapor dan korban), dimana korban tidak termasuk dalam bagian dari unsur yang terlibat dalam sistem peradilan pidana sebagaimana terdakwa, polisi dan jaksa. Melalui penelitian ini, diharapkan agar perlindungan hakhak korban penganiayaan kedepannya dapat segera diambil langkah-langkah antara lain dalam hukum acara pidana nasional memuat ketentuan yang jelas, tegas, dan berimbang mengenai perlindungan terhadap hak-hak korban penganiayaan dan demi tercapainya tujuan penegakan hukum maka kiranya perlu dilakukan upaya pembaharuan hukum pidana atau upaya melakukan peninjauan dan pembentukan kembali (reorientasi dan reformasi) ketentuan hukum acara pidana mengenai perlindungan terhadap korban penganiayaan.
\end{abstract}

\section{KATA KUNCI : \\ Perlindungan Hukum, Korban Penganiayaan dan Hak-hak korban}

\section{A. PENDAHULUAN}

\section{Latar Belakang}

Negara Indonesia adalah negara hukum (rechtsstaat) dimana hukum pada dasarnya bertujuan untuk mencapai kedamaian hidup bersama, yang merupakan keserasian antara ketertiban dan ketentraman. ${ }^{1}$

Indonesia sebagai negara hukum memberikan perlindungan bagi warga negaranya dengan menyediakan lembaga yang mampu memberikan keadilan dalam bentuk peradilan yang bebas dan tidak memihak. Hal ini didasari pandangan bahwa setiap manusia sejak kelahirannya menyandang hak-hak dan kewajiban yang bersifat bebas dan asasi, negara serta penyelenggaraan kekuasan suatu negara tidak boleh mengurangi arti atau makna kebebasan dan hak-hak asasi kemanusian itu.

Salah satu bentuk perlindungan terhadap masyarakat yang harus dilakukan oleh negara adalah memberikan perlindungan hukum melalui proses peradilan apabila terjadi tindak pidana atau disebut sebagai sistem peradilan pidana (criminal justice sistem). Salah satu pihak yang sangat membutuhkan perlindungan dalam suatu tindak pidana adalah korban tindak pidana. Peran penting korban untuk diberikan perhatian dan perlindungan berangkat dari pemikiran bahwa korban merupakan pihak yang dirugikan dalam terjadinya suatu

\footnotetext{
${ }^{1}$ Soejono Soekanto, Sosiologi Suatu Pengantar, PT. Raja Grafindo Persada, Jakarta, 2007, hal 179.
} 
kejahatan sehingga harus mendapat perhatian dan pelayanan dalam rangka memberikan perlindungan terhadap kepentingannya.

Korban tindak pidana lemah dalam perlindungan hukum, sejak korban melaporkan terjadi tindak pidana dan menunjukkan siapa pelaku tindak pidana dan atau dengan menyerahkan barang bukti dan ditemukan ditempat kejadian perkara termasuk penderitaan baik fisik maupun non fisik serta kerugian materil dan kerugian non materil kepada aparat penegak hukum (POLRI). Dengan korban telah melaporkan hal tersebut diatas, maka korban tidak memiliki akses untuk mendapatkan foto copy arsip laporan polisi. Berita acara pemeriksaan korban/pelapor dan saksi, surat perintah penyidikan, surat perintah penuntutan, berkas perkara yang diserahkan kepada jaksa penuntut umum, pelimpahan tersangka dan barang bukti kepada jaksa penuntut umum, pelimpahan surat dakwaan kepada pengadilan negeri, dakwaan dan tuntutan pidana serta putusan pengadilan negeri apalagi untuk mendapatkan kompensasi atas penderitaan dan kerugian yang diderita oleh pihak korban sampai mempunyai kekuatan hukum tetap. ${ }^{2}$

Dalam proses persidangan terhadap sebuah perkara pidana, korban menempati posisi yang penting untuk dapat mengungkap peritiwa pidana tersebut namun selama ini pembuat undang-undang dan para penegak hukum umumnya hanya tertuju pada pelaku tindak pidana dalam hal bagaimana menemukan cara atau metode penjatuhan sanksi yang lebih tegas dan adil agar pelaku kejahatan merasa jera atau mencegah orang untuk melakukan kejahatan. Lebih lanjut disebutkan bahwa fokus perhatian pada korban kejahatan sering menjadi terabaikan karena selama ini keberadaan korban dalam proses peradilan pidana khususnya pada tahap penyidikan nampaknya kurang mendapat perhatian dan kurang mendapat perlindungan hukum. Sebagai seorang korban kejahatan, ia mempunyai hak seperti manusia lainnya, sebagaimana dijamin dalam konvensi-konvensi hak asasi manusia dan secara legal dilindungi oleh perjanjian tersebut. ${ }^{3}$

Ketentuan-ketentuan mengenai perlindungan terhadap korban kejahatan di dalam Kitab Undang-undang Hukum Acara Pidana lebih dominan memberikan pengaturan mengenai ganti rugi sebagaimana diatur dalam Pasal 98 sampai dengan 101 KUHAP. Penggabungan perkara perdata dan pidana memang diatur dalam pasal 98 KUHAP namun penggabungan perkara tersebut jarang terjadi dimana korban lebih memilih melakukan tuntutan ganti kerugian setelah perkara pidananya telah memperoleh kekuatan hukum yang tetap.

Perlindungan terhadap korban pada dasarnya telah diatur dalam beberapa peraturan perundang-undangan di Indonesia sebagai pengejawantahan hak-hak asasi manusia dalam konstitusi dan hak-hak korban dalam KUHAP. Peraturan perundang-undang yang dimaksud adalah Undang-Undang Republik Indonesia No. 13 Tahun 2006 tentang Perlindungan Saksi dan Korban, Peraturan Pemerintah No. 27 tahun 1983. Pelaksanaan Kitab Undang-undang Hukum Acara Pidana, mengarahkan negara melalui Depertemen Keuangan dibebani tanggung jawab untuk menyelesaikan pembayaran ganti kerugian yang dikabulkan pengadilan. Dalam UU No. 13 tahun 2006, restitusi dapat diberikan kepada semua korban tindak pidana yang terjadi dan tidak terbatas pada korban pelanggaran HAM yang berat sebagaimana hak atas kompensasi yang diatur dalam UU Pengadilan Hak Asasi Manusia.

Sistem peradilan pidana mengutamakan perlindungan hak-hak asasi manusia, namun apabila ketentuan-ketentuan mengenai hal itu diperhatikan secara lebih mendalam,

\footnotetext{
2 Abdussalam. Victimologi. PTIK Press, Jakarta 2010. HIm. 36

3 Ansori. 2011. Perlindungan Hukum Terhadap Korban Perkosaan Dalam Peradilan Pidana di Indonesia. Disertasi. Universitas Brawijaya : Malang. HIm. 1
} 
ternyata hanya hak-hak tersangka/terdakwa yang banyak ditonjolkan sedangkan hak-hak dari korban tindak pidana sangat sedikit diatur.

Pelaku kejahatan sejak awal telah dilingkupi oleh berbagai bentuk perlindungan hukum, seperti memperoleh bantuan hukum, memperoleh perlakuan yang baik dijauhkan dari penyiksaan, diberitahukan tentang kejahatan yang dituduhkan kepadanya, diberi hak untuk mengajukan ganti kerugian, dan rehabilitasi apabila ditangkap, ditahan, atau diadili tanpa alasan berdasarkan undang-undang. ${ }^{4}$

Perlindungan dan bantuan bagi korban tindak pidana adalah hal mendesak dan penting untuk segera diimplementasikan. Minimnya pemberian perlindungan dan bantuan terhadap korban tindak pidana, justru memberi sumbangsih besar bagi merosotnya kualitas penegakan hukum dalam suatu negara. Dalam proses persidangan terhadap suatu perkara pidana, korban menempati posisi yang penting untuk dapat terungkapnya suatu peristiwa pidana, salah satu korban yang dimaksud adalah korban penganiayaan. Hal ini dapat dilihat dengan adanya beberapa kasus penganiayaan yang terjadi di Kota Tidore Kepulauan yang mengakibatkan korban luka berat dan belum mendapatkan perlindungan yang memadai terutama terhadap apa yang menjadi hak korban itu sendiri.

Pemberian kompensasi dan restitusi diatur secara rinci dalam Peraturan Pemerintah Nomor 2 tahun 2002 tentang kompensasi, restitusi dan rehabilitasi terhadap korban pelanggaran HAM berat; dan Peraturan Pemerintah Nomor 44 Tahun 2008 tentang pemberian kompensasi, restitusi, bantuan. Menurut ketentuan Pasal 8 Undang-Undang Perlindungan Saksi dan Korban menentukan bahwa perlindungan dan hak korban diberikan sejak tahap penyelidikan dimulai dan berakhir sesuai dengan ketentuan sebagaimana diatur dalam Undang - Undang.

Perhatian terhadap kepentingan korban dapat dipandang sebagai unsur penting dalam rangka upaya penegakan hukum secara benar dan tepat, dalam hal ini fokus utama adalah pada perlakuan yang benar atau setepatnya terhadap pihak korban terutama ketentuan tentang penyediaan dan pemberian informasi yang dapat dimengerti kepada pihak korban, yang menderita kerugian akibat suatu tindak pidana oleh polisi maupun jaksa. ${ }^{5}$

Bertolak dari uraian diatas menggambarkan adanya kecenderungan tidak dilindunginya hak-hak korban hanya tertuju kepada pelaku penganiayaan padahal masalah keadilan dan penghormatan masalah hak asasi manusia tidak hanya berlaku terhadap pelaku saja tetapi juga terhadap korban.

\section{Rumusan Masalah}

Berdasarkan latar belakang tersebut, maka rumusan masalah dalam penelitian ini adalah :

- Bagaimanakah implementasi perlindungan hukum terhadap korban penganiayaan dalam penanganan tindak pidana di Kota Tidore Kepulauan?

\footnotetext{
4 Muhadar, dkk. Perlindungan Saksi dan Korban dalam Sistim Peradilan Pidana. Putra Media Nusantara, Surabaya, 2010. HIm. 50

${ }^{5}$ Muhadar, dkk, Perlindungan Saksi dan Korban dalam Sistem Peradilan Pidana, Putra Media Nusantara, Surabaya, 2010, HIm. 236
} 


\section{Tujuan Penelitian}

Berdasarkan rumusan masalah tersebut di atas, maka tujuan penelitian yang hendak dicapai, adalah :

- Untuk menganalisis pelaksanaan perlindungan hukum terhadap korban penganiayaan dalam penanganan tindak pidana di Kota Tidore Kepulauan.

\section{Manfaat Penelitian}

Dalam penelitian ini, diharapkan dapat dicapai beberapa manfaat baik dari aspek teoritis (keilmuan) maupun aspek praktis (guna laksana), sebagai berikut :

1. Secara teoritis, diharapkan hasil penelitian dapat dijadikan bahan referensi dalam pengembangan ilmu hukum khususnya dalam kajian hukum acara pidana.

2. Secara praktis, diharapkan hasil penelitian ini dapat memberikan masukan kepada semua pihak yang terkait dengan perlindungan hukum terhadap saksi dan korban dalam proses peradilan pidana termasuk para aparat penegak hukum dan pihak yang memiliki perhatian khusus dalam pengembangan sistem peradilan pidana yang bersih dan berwibawa serta memberikan perasaan keadilan bagi para pencari keadilan..

\section{B. TINJAUAN PUSTAKA}

\section{Perlindungan Hukum}

Perlindungan hukum berasal dari kata lindung yang artinya menempatkan diri di bawah sesuatu, supaya tersembunyi. Perlindungan memiliki pengertian suatu perbuatan yaitu melindungi, memberikan pertolongan. ${ }^{6}$ Sedangkan hukum menurut J.C.T. Simorangkir dan Woerjono Sastropranoto adalah peraturan-peraturan yang bersifat memaksa yang menentukan tingka laku manusia dalam lingkungan masyarakat yang dibuat oleh badan-badan resmi yang berwajib ${ }^{7}$

Menurut Philipus M. Hadjon, Pengertian perlindungan hukum dikaitkan dengan definisi perlindungan dan hukum adalah suatu perlindungan yang diberikan terhadap subjek hukum dalam bentuk perangkat hukum baik yang bersifat preventif maupun yang bersifat represif, baik yang tertulis maupun tidak tertulis. Perlindungan hukum sebagai suatu gambaran dari fungsi hukum, yaitu konsep di mana hukum dapat memberikan suatu keadilan, ketertiban, kepastian, kemanfaatan dan kedamaian. ${ }^{8}$

Dalam negara hukum, perlindungan hukum mencerminkan kewajiban dan tanggung jawab yang diberikan dan dijamin oleh negara untuk menghormati, melindungi, menegakkan dan memajukan hak-hak asasi manusia berdasarkan Undang-Undang dan peraturan hukum.

Dalam pandangan Setiono tentang perlindungan hukum adalah tindakan atau upaya untuk melindungi masyarakat dari perbuatan sewenang-wenang oleh penguasa

6 Peorwarminta, 1998, Kamus Bahasa Indonesia. Balai Pusataka : Jakarta Hlm. 540

7 J.C.T. Simorangkir dan Woerjono Sastropratnoto, Hukum Indonesia. Pustaka Gunung Agung : Jakarta. HIm, 32

8 Philipus M. Hadjon. Perlindungan Hukum Bagi Rakyat di Indonesia, Sebuah Studi Tentang Prinsip-Prinsip Penerapannya Oleh Pengadilan Dalam Lingkungan Peradilan Umum dan Pembentukan Peradilan Administrasi Negara. Bina Ilmu. 1987. Surabaya. HIm. 1 
yang tidak sesuai dengan aturan hukum, mewujudkan ketertiban dan ketentraman sehingga memungkinkan manusia untuk menikmati martabatnya sebagai manusia. ${ }^{9}$

Salah satu fungsi hukum adalah untuk memberi perlindungan dimana hukum itu ditumbuhkan dan dibutuhkan manusia justru berdasarkan produk penelitian manusia untuk menciptakan kondisi yang melindungi dan memajukan martabat manusia serta untuk memungkinkan manusia menjalani kehidupan yang wajar sesuai dengan martabatnya. ${ }^{10}$

Di samping itu hukum adalah memperoleh setinggi-tinggi kepastian hukum (rechtzeker heid). Kepastian hukum menjadi makin dianggap penting bila dikaitkan dengan ajaran negara berdasarkan atas hukum. Telah menjadi klasik dalam ilmu hukum tertulis lebih menjamin kepastian hukum dibandingkan dengan hukum tidak tertulis.

Phlipus M. Hadjon, dalam pandangannya yang menempatkan perlindungan hukum sebagai sesuatu yang memungkinkan seseorang dapat melaksanakan dan mempertahankan hak-haknya yang ditentukan oleh hukum dan kaitanya tindakan pemerintah sebagai titik sentral maka Philips M. Hadjon, mengemukakan bahwa ada 2 (dua) macam perlindungan hukum bagi rakyat yaitu :

a) Perlindungan hukum yang preventif

Pada perlindungan hukum yang preventif, kepada rakyat diberikan kesempatan untuk mengajukan keberatan atau pendapatnya sebelum suatu keputusan pemerintah mendapat bentuk yang difinitif. Dengan demikian, perlindungan preventif bertujuan mencegah terjadinya sengketa.

b) Perlindungan hukum yang represif

Dalam perlindungan hukum yang represif, rakyat diberikan kesempatan mengajukan keberatan setelah adanya akibat dari suatu keputusan pemerintah yang definitif dalam arti bahwa perlindungan represif bersifat menyelesaikan masalah. ${ }^{11}$

Tahir Azhari, memperkenalkan pula istilah perlindungan hukum formal dan substantif. Perlindungan hukum formal adalah perlindungan hukum yang mangacu pada pelaksanaan hak-hak dan secara formal diterapkan dalam peraturan perundangundangan dan atau perjanjian. Perlindungan hukum subtantif adalah perlindungan hukum yang mengacu pada pelaksanaan hak-hak yang secara subtantif melekat pada hukum. Artinya meskipun tidak diterapkan dalam undang-undang namun pelaksanannya melekat pada orang/aktivitasnya. ${ }^{12}$

Negara hukum pada hakikatnya bersinggungan dengan persoalan tentang dua sentra kekuasaan. Di satu pihak terdapat negara dengan kekuasaan yang menjadi

9 Setiono. Rule Of Low (Supermasi Hukum). Surakarta. 2004. HIm. 3

10 Lili Rasjidi dan B. Arief Sidharta. Filsafat Hukum Madzab dan Refleksi. Remaja Rosida Karya : Bandung. 1994. HIm. 64

11 Philipus M. Hadjon. Perlindungan Hukum Bagi Rakyat Indonesia, Sebuah Studi Tentang Prinsipprinsipnya, Penerapannya oleh Pengadilan Dalam Lingkungan Peradilan Umum dan Pembentukan Peradilan Administrasi Negara. Bina Ilmu : Surabaya. 1987. HIm. 2

12 Muhammad Tahir Azhary. Negara Hukum Indonesia Analisis Yuridis Normatif Tentang Unsur-Unsurnya. U-Press : Jakarta. 1995. HIm. 1 
syarat mutlak untuk dapat memerintah. Di lain pihak nampak rakyat yang diperintah segan melepaskan segala kekuasaannya.

Van Apeldoorn, mengemukakan bahwa tujuan hukum ialah mengatur tata tertib masyarakat secara damai dan adil. Perdamaian di antara manusia dipertahankan oleh hukum dengan melindungi kepentingan-kepentingan manusia tertentu, kehormatan, kemerdekaan, jiwa harta dan sebagainya terhadap yang merugikannya. Kepentingan dari perorangan dan kepentingan golongan manusia selalu bertentangan satu sama lain, pertentangan kepentingan selalu menyebabkan pertikaian. Hukum mempertahankan perdamaian dengan menimbang kepentingan yang bertentangan secara teliti dan mengadakan keseimbangan diantaranya karena hukum hanya dapat mencapi tujuan (mengatur pergaulan hidup secara damai) jika ia menuju peraturan yang adil. Peraturan yang mengandung keseimbangan antara kepentingan-kepentingan yang dilindungi sehingga setiap orang memperoleh sebanyak mungkin yang menjadi bagiannya ${ }^{13}$.

Undang-Undang Nomor 13 Tahun 2006 tentang Perlindungan Saksi dan Korban memberikan perlindungan dan bantuan terhadap saksi maupun korban. Perlindungan dimaksud adalah dalam bentuk perbuatan yang memberikan tempat bernaung atau perlindungan bagi seseorang yang membutuhkan sehingga merasa aman terhadap ancaman sekitarnya. ${ }^{14}$

Berdasarkan Pasal 5 UU RI Nomor 13 Tahun 2006 tentang Perlindungan Saksi dan Korban disebutkan :

1. memperoleh perlindungan hukum atas keamanan pribadi, keluarga, dan harta bendanya, serta bebas dari ancaman yang berkenaan dengan kesaksian yang akan, sedang atau telah diberikannya ;

2. ikut serta dalam proses memilih dan menentukan bentuk perlindungan dan dukungan keamanan ;

3. memberikan keterangan tanpa tekanan ;

4. mendapat penerjemah ;

5. bebas dari pertanyaan yang menjerat ;

6. mendapat informasi mengenai perkembangan kasus ;

7. mendapat informasi mengenai putusan pengadilan ;

8. mengetahui dalam hal terpidana dibebaskan ;

9. mendapat identitas baru ;

10. mendapatkan tempat kediaman baru ;

11. memperoleh penggantian biaya tranfortasi sesuai dengan kebutuhan ;

12. mendapat nasehat hukum; dan /atau

13. memperoleh bantuan biaya hidup sementara sampai batas waktu perlindungan terakhir.

Menurut ketentuan Pasal 6 Undang-Undang Perlindungan Saksi dan Korban menentukan bahwa korban dalam pelanggaran HAM yang berat, selain berhak atas hak sebagaimana dimaksud dalam Pasal 5, juga berhak untuk mendapatkan :

1. Bantuan medis;

2. Bantuan rehabilitasi psiko-sosial.

13 Van Apeldoorn dalam ibid. HIm. 89

14 Muhadar dkk. Perlindungan Saksi dan Korban Dalam Sistem Peradilan Pidana. Putera Media Nusantara : Surbaya. 2010. HIm. 104 
Demikian juga ketentuan Pasal 7 Undang-Undang Perlindungan Saksi dan Korban menentukan :

1. Korban melalui LPSK berhak mengajukan ke pengadilan berupa :

a. hak atas kompensasi dalam kasus pelanggaran hak asasi manusia yang berat ;

b. hak atas restitusi atau ganti kerugian yang menjadi tanggungjawab pelaku tindak pidana.

2. Keputusan mengenai konpensasi dan retitusi diberikan oleh pengadilan

3. Ketentuan lebih lanjut mengenai pemberian kompensasi dan restitusi diatur dengan Peraturan Pemerintah.

Ketentuan-ketentuan mengenai perlindungan terhadap korban tindak pidana di dalam Kitab Undang-Undang Hukum Acara Pidana lebih dominan memberikan pengaturan mengenai ganti rugi yang dapat dikelompokkan dalam 4 (empat) bentuk hakhak korban yaitu: ${ }^{15}$

a. Hak untuk melakukan kontrol terhadap tindakan penyelidik dan penuntut umum, yakni hak mengajukan keberatan atas tindakan penghentian penyelidikan dan/atau penuntutan dalam kapasitasnya sebagai pihak ketiga yang berkepentingan sebagaimana diatur dalam Pasal 109 dan 140 ayat (2) KUHAP;

b. Hak korban dalam kedudukannya sebagai saksi, sebagaimana diatur dalam Pasal 168 KUHAP;

c. Hak bagi korban, untuk mengizinkan atau tidak mengizinkan polisi atas tindakan polisi melakukan bedah mayat atau penggalian kubur untuk otopsi Hal ini di atur dalam Pasal 134 sampai 136 KUHAP.

d. Hak menuntut ganti rugi atas kerugian yang diberikan dari akibat tindak pidana dalam kapasitasnya sebagai pihak yang dirugikan sebagaimana diatur dalam Pasal 98 sampai dengan Pasal 101 KUHAP.

Kelemahan pengaturan Kitab Undang-Undang Hukum Acara Pidana (KUHAP) dalam mengatur mengenai korban dalam pandangan Barda Nawawi Arief ${ }^{16}$ adalah sebagai berikut :

a. Tidak ada upaya hukum yang dapat dilakukan korban jika tidak puas dengan suatu putusan pengadilan. Hal ini berbeda dengan tersangka, yang dapat melakukan upaya hukum banding, kasasi, ataupun peninjauan kembali. Korban yang diwakili oleh jaksa sebagai penuntut umum hanya bisa menerima putusan tersebut.

b. Perlindungan terhadap korban kejahatan hanya diatur di dalam Bab XII (Pasal 98101) KUHAP, yang memungkinkan penggabungan perkara gugatan ganti kerugian kepada perkara pidana.

c. Pasal 99 KUHAP menegaskan bahwa ganti kerugian yang dapat diputuskan oleh Hakim hanyalah biaya lainnya hanya dapat digugat melalui peradilan perdata yang prosesnya memakan waktu yang lama dan memulai procedural acara baru.

d. Hakim dapat menetapkan syarat khusus bahwa terpidana dalam waktu tertentu, yang lebih pendek dari pada masa percobannya, harus mengganti seluruh atau sebagai kerugian yang ditimbulkan oleh tindak pidana tersebut atau dengan kata lain bahwa hak korban tindak pidana kejahatan hanya berlaku bila Hakim menjatuhkan hukuman percobaan sedangkan dalam hal kejahatan yang menimbulkan

\footnotetext{
${ }^{15}$ Muhaddar dkk. Perlindungan Saksi dan Korban Dalam Sistem Peradilan Pidana, Putra Media Nusantara Surabaya, 2010, HIm 51

16 Barda Nawawi, Perbandingan Hukum Pidana, Raja Grafindo Persada, Jakarta, 2002 hlm.6
} 
kerugian besar atau kejahatan dengan kekerasan, hukuman percobaan sulit untuk dijatuhkan.

e. Pembayaran yang dibebankan kepada pelaku berupa ganti kerugian dibatasi hanya atas nilai yang bersifat materil.

\section{Konsepsi Tentang Korban}

\section{a. Defenisi Korban}

Secara istilah korban berasal dari bahasa latin victim dalam Declaration of Bacic Principles of Justice for Victims of Crime and Abuse of Power adalah orang baik secara individu maupun kolektif telah menderita kerugian baik fisik, mental, emosional maupun pembusukan (imparirment) terhadap hak-hak dasar mereka baik melalui perbuatan maupun tidak, namun merupakan pelanggaran terhadap hukum pidana nasional di samping juga berdasarkan norma-norma internasional diakui berkaitan dengan hak asasi manusia ${ }^{17}$

Korban adalah merupakan orang yang mengalami kerugian baik kerugian fisik, mental maupun kerugian finansial yang merupakan akibat dari satu tindak pidana (sebagai akibat) atau merupakan sebagai salah satu faktor timbulnya tindak pidana (sebagai sebab). Korban diartikan sebagai seseorang yang telah menderita kerugian sebagai akibat tindak pidana dan rasa keadilannya secara target/sasaran tindakan pidana". ${ }^{18}$

Stanciu, menyebutkan bahwa korban dalam pengertian yang luas adalah orang yang menderita akibat dari ketidakadilan. Ada dua sifat yang mendasar yang melekat pada korban yaitu pertama yang disebut suffering (penderitaan) dan injustice (ketidakadilan). Korban tidak hanya dapat dipandang sebagai akibat perbuatan yang illegal sebab sebenarnya juga dapat menimbulkan ketidakadilan, selanjutnya menimbulkan korban. Pengertian dibatasi pula dalam arti sempit sebagaimana diatur dalam hukum positif. ${ }^{19}$

Definisi di atas menunjukakan bahwa korban kejahatan diartikan sebagai orang yang secara perorangan atau bersama-sama, menderita kerugian, termasuk kerugian fisik atau mental, penderitaan emosional, kerugian ekonomis atau pelemahan substansial dari hak-hak dasar mereka, melalui tindakan atau kelalaian yang merupakan penggaran terhadap hukum yang berlaku di negara-negara anggota termasuk hukum-hukum yang melarang penyalahgunanan kekuasaan yang bersifat pidana. ${ }^{20}$

17 Benjamin Mendelsohn dalam Ira Dwiati. 2007. Perlindungan Hukum Terhadap Korban Tindak Pidana Perkosaan Dalam Peradilan Pidana. HIm. 76

18 Sujoko. Implementasi Tuntutan Ganti Kerugian dalam Pasal 98 KUHP Terhadap Tindak Pidana Pemerkosaan. Universitas Dipenorogo. 2008. HIm. 1

19 V.V. Stanciu dalam ibid. HIm. 29.

20 United Nation Declaration of Basic Principles of Victims of Crime and Abuse of Power 29 November 1985. File Naska deklarasi di download dari http:/www.unrol,org/filea/BASICP-4PDF. 


\section{b. Jenis-Jenis Korban dan Perlindungan Korban}

Konsepsi korban tindak pidana termasuk juga dalam Declaration of Basic Principlesof Justice for Victim of Crime and Abuse of Power, Power, yaitu :21

1) Korban Langsung (direct victims) yaitu korban yang langsung mengalami dan merasakan penderitaan dengan adanya tindak pidana dengan karakteristik korban adalah orang baik secara individu atau kolektif, menderita kerugian berupa luka fisik, luka mental, penderitaan emosional, kehilangan pendapatan dan penindasan hak-hak dasar manusia, disebabkan adanya perbuatan atau kelalaian yang terumuskan dalam hukum pidana atau disebabkan adanya penyalagunaan kekuasaan.

2) Korban tidak lansung (indirect victims) yaitu timbulnya korban akibat dari campurnya seseorang dalam membantu korban langsung (direct victims) atau turut melakukan pencegahan timbulnya korban, tetapi dia sendiri menjadi korban tindak pidana, atau mereka menggantungkan hidupnya kepada korban langsung seperti isteri/suami, anak-anak dan keluarga terdekat.

3) Victims of abuse of power yaitu korban adalah yang secara individual atau kolektif menderita kerugian, termasuk luka fisik atau mental, penderitaan emosional, kehilangan ekonomi atau pelanggaran terhadap pokok-pokok hak dasar mereka, melalui perbuatan-perbuatan atau kelalaian yang belum merupakan. pelanggaran undang-undang pidana nasional tetapi norma-norma diakui secara internasional yang berhubungan dengan hak-hak asasi manusia.

Mardjono Reksodiputro, mengemukakan pula pandangan bahwa ada 4 (empat) macam pengertian korban yaitu. ${ }^{22}$

1. Korban kejahatan konvesional seperti pembunuhan, perkosaan, penganiayaan, pencurian

2. Korban kejahatan non konvesional seperti terorisme, pembajakan, perdagangan narkotika secara tidak sah, kejahatan terorganisasi dan kejahatan melalui computer.

3. Korban penyalagunaan secara melawan hukum kekuasaan ekonomi (illegal abuses of economic power) seperti pelanggaran terhadap peraturan perburuhan, penipuan konsumen, pelanggaran terhadap peraturan lingkungan, penyelewengan di bidang pemasaran dan perdagangan oleh perusahaanperusaan trans-nasional, pelanggaran peraturan devisa, pelanggaran peraturan pajak dan sebagainya.

4. Korban penyalahgunaan secara melawan hukum kekuasaan umum (illegal abuses of public power) seperti pelanggaran terhadap hak asasi manusia, penyalahgunaan wewenang oleh alat penguasa, termasuk penangkapan serta penahanan yang melanggar hukum dan lain sebagainya

Tujuan perlindungan korban adalah memberikan ketentraman rasa aman kepada korban khususnya pada saat memberikan keterangan pada setiap proses peradilan pidana, memberikan dorongan dan motivasi kepada korban agar tidak takut dalam menjalani proses peradilan pidana, memulihan rasa percaya diri korban dalam

21 Bambang Djoyo Supeno. Penerapan Hukum Bagi Koruptor Masih Timpang. Semarang. HIm. 2

22 Mardjono Reksodiputro. Kriminolgi dan Sistem Peradilan Pidana (Kumpulan Karangan, buku kedua), Pusat Pelayanan Keadilan dan Pengabdian Hukum (d/h Lembaga Kriminologi) Universitas Indonesia : Jakarta. 2007. HIm. 8586 
hidup bermasyarakat, dan memulai rasa keadilan, bukan hanya kepada korban dan keluarga korban, tapi juga kepada masyarakat ${ }^{23}$

\section{c. Faktor Yang Mempengaruhi Perlindungan Hukum terhadap Korban Kejahatan}

Setiap norma hukum sudah dengan sendirinya mengandung kebutuhan tentang hak-hak dan kewajiban-kewajiban para subyek hukum dalam lalu lintas hukum. Norma-norma hukum yang bersifat dasar, tentulah berisi rumusan hak-hak dan kewajiban-kewajiban yang juga dasar dan mendasar. Oleh karena itu, secara akademis, sebenarnya persoalan hak dan kewajiban asasi manusia memang menyangkut konsepsi yang niscaya ada dalam keseimbangan konsep hukum dan keadilan. Dalam setiap hubungan hukum terkandung di dalamnya dimensi hak dan kewajiban secara pararel dan bersilang. Kekuasaan yang diorganisasikan ke dalam dan melalui organ-organ negara, seringkali terbukti melahirkan penindasan . oleh karena itu, sejarah umat manusia mewariskan gagasan perlindungan dan penghormatan terhadap hak-hak asasi manusia.

Marwanto Heru Santoso ${ }^{24}$ mengemukakan bahwa gagasan perlindungan dan penghormatan hak asasi manusia ini bahkan diadopsi ke dalam pemikiran mengenai pembatasan kekuasan yang kemudian dikenal dengan aliran konstitusionalisme, aliran konstitusionalisme inilah yang memberi warna modern terhadap ide-ide demokrasi dan nomokrasi (negara hukum) dalam sejarah, sehingga perlindungan konstitusional terhadap hak asasi manusia dianggap sebagai ciri utama yang perlu ada dalam setiap negara hukum yang demokratis (demoocratitutional rechsstaat) ataupun negara demokrasi yang berdasar pada hukum (constitutional democracy).

Dalam proses bekerjanya aparatur penegak hukum itu, terdapat 3 (tiga) elemen penting yang mempengaruhi, yaitu: ${ }^{25}$

a. Institusi penegak hukum beserta berbagai perangkat sarana dan prasarana pendukung dan mekanisme kerja kelembagaannya;

b. Budaya kerja yang terkait dengan aparatnya, termasuk mengenai kesejahteraan aparatnya, dan

c. Perangkat peraturan yang mendukung baik kinerja kelembagaannya maupun yang mengatur material hukum yang dijadikan standar kerja, baik hukum materilnya maupun hukum acaranya.

Upaya penegak hukum secara sistematik haruslah memperhatikan ketiga aspek itu secara simultan, sehingga proses penegakan hukum dan keadilan itu sendiri secara internal dapat diwujudkan secara nyata.

Hikmahanto Juwana, mengemukakan bahwa bagi masyarakat Indonesia, lemah kuatnya penegakan hukum oleh aparat akan menentukan persepsi ada tidaknya hukum. Bila penegakan hukum oleh aparat lemah, masyarakat akan memeprsepsikan hukum sebagai tidak ada seolah mereka berada dalam hutan rimba. Sebaliknya, bila

\footnotetext{
23 Pasal 4 UU No. 13 Tahun 2006 Tentang Perlindungan Saksi dan Korban

${ }^{24}$ Marwanto Heru Santoso. Polisi dalam Era Reformasi, Makala : Jakarta. 1998. HIm. 13

${ }^{25}$ Ibid HIm. 4
} 
penegakan hukum oleh aparat kuat dan dilakukan secara konsisten, barulah masyarakat mempersepsikan hukum ada dan akan tunduk. ${ }^{26}$

Masyarakat Indonesia masih dalam taraf masyarakat yang "takut" pada hukum (aparat penegak hukum) dan belum dapat dikategorikan sebagai masyarakat sebagai yang 'taat' pada hukum. Pada masyarakat yang takut pada hukum, masyarakat tidak akan tunduk pada hukum bila penegakan hukum lemah, inkonsisten dan tidak dapat dipercaya. Realitas saat ini penegakan hukum berfungsi dan difungsikan sebagai instrumen untuk membuat masyarakat takut pada hukum yang pada gilirannya diharapkan menjadi taat pada hukum. ${ }^{27}$

Keluhan berkenaan dengan kinerja penegakan hukum di Indonesia selama ini, sebenarnya juga memerlukan analisis yang lebih menyeluruh lagi. Upaya penegakan hukum hanya satu elemen saja dari keseluruhan persoalan kita sebagai negara hukum yang mencita-citakan upaya menegakkan dan mewujudkan keadilan sosial bagi seluruh rakyat Indonesia. Hukum tidak mungkin akan tegak, jika hukum itu sendiri tidak atau belum mencerminkan perasaan atau nilai-nilai keadilan yang hidup dalam masyarakatnya, hukum tidak mungkin menjamin keadilan jika materinya sebagian besar merupakan warisan masa lalu yang tidak sesuai lagi dengan tuntutan zaman. Persoalan yang dihadapi bukan saja berkenaan dengan upaya penegakan hukum tetapi juga pembaharuan hukum atau pembuatan hukum baru. ${ }^{28}$ yaitu : ${ }^{29}$

Ada 4 (empat) fungsi penting yang memerlukan perhatian yang seksama, a. Pembuatan hukum (the legislation of law atau law and rule making),

b. Sosialisai, penyebarluasan dan bahkan pembudayaan hokum (socialization and promulgation of law) dan

c. Penegakan hukum (the enforcement of law)

Ketiganya membutukan dukungan (d) administrasi hukum (the administration) yang efektif dan efisien yang dijadikan oleh pemerintah (eksekutif) yang bertanggung jawab (accountable). Karena itu, pengembangan administrasi hukum dan sistem hukum dapat disebut sebagai agenda penting yang keempat sebagai tambahan terhadap ketiga agenda tersebut di atas.

The administration of law itu mencakup pengertian pelaksanaan hukum (rules executing) dan tata administarsi hukum itu sendiri dalam dalam pengertian yang sempit. Misalnya dapat dipersoalkan sejauh mana sistem ini telah dikembangkan dalam rangka pendokumentasian peraturan-peraturan (rege/s), keputusan-keputusan administrasi negara (beschikings), ataupun penetapan dan putusan (vonis) hakim di seluruh jajaran dan lapisan pemerintahan dari pusat sampai ke daerah-daerah. ${ }^{30}$

Untuk memahami secara lebih cermat tentang sistem hukum, maka harus dicermati unsur-unsur yang terdapat di dalam sistem hukum itu. Sistem hukum

\footnotetext{
26 Hikmahanto Juwana. Penegakan Hukum Bidang Lalu Lintas. Citra Pratama: Jakarta. 2001. HIm.11

27 Prabowo dan Dwi Riyanti. Masalah Kejiwaan dalam Berbagai Profesi. Sinar Grafika:Jakarta.1998. HIm. 2

28 Ibid. HIm. 3

29 Satjipto Raharjo dalam Ibid. HIm. 5

30 Harsja W. Bactiar. Ilmu Kepolisian, Suatu Cabang Ilmu Pengetahuan yang Baru. Grassindo:Jakarta 1994.
} 
mempunyai tiga unsur yaitu struktur, substansi dan kultur. Sebagaimana dinyatakan oleh Lawrence M. Friedman bahwa :

"A legal system in actual operation is a complex organism in which structure, substance, and culture interact. To explainthe background and effect of any part calls into play many elementsof the system. ${ }^{31}$ "

Pandangan diatas menunjukkan bahwa sistem hukum dalam kegiatangnya menjalankan sebenarnya merupakan gabungan struktur, substansi, dan budaya yang saling berhubungan dan menjelaskan begitu banyaknya unsur sistem. Selanjutnya Sudikno Mertokusumo ${ }^{32}$, menyatakan, bahwa dalam penegakan hukum hanya diperhatikan kepastian hukum saja, maka unsur-unsur lainnya dikorbankan. Demikian pula kalau yang diperhatikan hanyalah kemanfaatannya, maka kepastian hukum dan keadilan dikorbankan dan perhatian secara proposional seimbang akan tetapi, dalam praktik tidak selalu mudah mengusahakan kompromi secara proposional seimbang antara ketiga unsur tersebut.

Daniel S. Lev dalam Satjipto Rahardjo., yang menyatakan, bahwa apabila kekuatan para pejabat hukum seperti Hakim, Jaksa, Polisi dan Advokat berubah, maka hal itu berarti hukum juga sudah berubah, walaupun undang-undang dan peraturanperaturan lainnya masih tetap saja seperti dahulu. Hukum yang dimaksudkan Daniel S. Lev dalam hal ini, adalah bukan undang-undang dan peraturan-peraturan hukum yang anggapnya sebagai pengertian yang sempit, tetapi yang merupakan hukum adalah praktik sehari-hari oleh para pejabat hukum itu. ${ }^{33}$

Selanjutnya menurut Soerjono Soekanto, terdapat (lima) faktor yang sangat mempengarui penegakan hukum, kelima faktor tersebut saling berkaitan erat, sehingga merupakan esensi dari penegkan hukum dan merupakan tolak ukur dari efektivitas penegakan hukum. Kelima faktor tersebut, adalah ${ }^{34}$ :

1. Faktor hukum sendiri, terutama undang-undang.

2. Faktor penegak hukum, yakni pihak-pihak yang membuat dan menerapkan hukum .Faktor sarana atau fasilitas yang mendukung penegakan hukum.

3. Faktor masyarakat, yakni lingkungan di mana hukum tersebut berlaku atau di terapkan.

4. Faktor kebudayaan, yakni sebagai hasil karya cipta dan rasa di dasarkan pada karsa manusia di dalam pergaulan hidup.

Berdasarkan uraian di atas, jelas bahwa faktor-faktor yang dapat mempengaruhi pelaksanaan atau penegakan hukum cukup banyak dan bervariasi. Akan tetapi, keseluruhan faktor tersebut faktor manusia yang menjalankan penegakan hukum itu sangat dominan untuk menentukan apakah penegakan hukum (pelayan penegakan hukum) itu berhasil atau tidak.

31 Lawrence Friedman. The Legal System A Social Science Perspective. Russel Sage Foundation:New York. 1975. HIm. 16

32 Sudikno Mertokusumo. 1993. Bab-bab Tentang Penemuan Hukum. PT. Citra Aditya bekerja sama dengan Konsorsium Ilmu-ilmu Hukum, Departemen Pendidikan dan Kebudayaan dan The Asia Fodation: Bandung. HIm.2

33 Satjipto Raharjo dan Anton Tabah. Polisi, Pelaku, dan Pemikir. Gramedia Pustaka Utama, Jakarta. 1993. HIm. 65

34 Soejono Soekanto. Beberapa Catatan Tentang Psikilogi Hukum. PT. Citra Aditya Bhakti : Bandung 1993. HIm. 5-6 


\section{Peradilan Pidana}

Penyelenggaraan peradilan pidana merupakan mekanisme bekerjanya aparat penegak hukum pidana mulai dari proses penyelidikan dan penyidikan, penangkapan, penahanan penuntutan, sampai pemeriksaan di sidang pengadilan atau dengan kata lain bekerjanya polisi, jaksa, hakim dan petugas lembaga pemasyarakatan demi mencapai tujuan peradilan pidana. ${ }^{35}$ Peradilan pidana merupakan suatu sistem karena dalam peradilan pidana terdapat beberapa lembaga yang masing-masing mempunyai wewenang dan tugas sesuai dengan bidangnya dan sesuai peraturan yang berlaku. Dalam peradilan pidana terdapat beberapa komponen namun sasaran semua lembaga adalah menanggulangi kejahatan dan mencegah kejahatan. ${ }^{36}$

Dalam masyarakat terdapat sejumlah sistem dan subsistem yang dapat mempengaruhi kehidupan manusia, salah satunya adalah sistem peradilan pidana. Terkait dengan hal ini, J.W. La Patra mengemukakan : ${ }^{37}$

Many different societal sytems have an impactan an individual before he has contact with the criminal justice system. $H$ is bron witn ertain mental is physical abilitess and particular tendencies that may inherited. In the course of his life he comes in contact with may inherited. In the course of his life he comes in contact with various group, such as the family. Which important roles ion his life other societal system scononic, eduatinal, tehcnolical play and political among others have a substansial influence on his life.

Patra dalam kutipan di atas mengemukakan bahwa banyak sistem yang berbeda dalam bermasyarakat, yang mempunyai dampak pada perorangan sebelum ia mempunyai hubungan dengan peradilan pidana. la adalah pembawaan mental sejak lahir yaitu fisik, kemampuan dan kecenderungan untuk dapat menerima warisan. Selama hidupnya ia datang dalam hubungan dengan berbagai kelompok seperti keluarga. Peran penting dalam hidup masyarakat antara sistem ekonomi, teknologi, politik dan hubungan antara orang yang mempunyai suatu substansi yang mempengarui dalam hidupnya.

Administrasi peradilan pidana yang dilaksanakan oleh para penegak hukum berlangsung berdasarkan kaidah-kaidah hukum acara pidana. Beberapa karangan mengenai hukum acara pidana yang ditulis ahli hukum acara pidana di Belanda mengemukakan bahwa hukum acara mengatur : ${ }^{38}$

a) Diutusnya kebenaran atas adanya persangkaan dilanggarnya undang-undang pidana. Pengusutan dilakukan oleh alat negara yang khusus diadakan untuk keperluan tersebut;

b) Diusahakan untuk mengusut para pelaku tindak pidana atau perbuatan yang melanggar undang-undang pidana itu;

c) Diikhawatirkan segala daya upaya agar pelaku perbuatan ditangkap jika perlu ditahan;

d) Alat bukti yang diperoleh dan berkumpul dari pengusutan dari kebenaran persangkutan melalui proses penuntutan diserahkan kepada hakim agar tersangka dapat dihadapkan kepada hakim;

e) Penyerahan kepada hakim adalah untuk diambil keputusan tentang terbukti tidaknya perbuatan yang disangkakan;

\footnotetext{
35 Yemil Anwar dan Adang. Sistem Peradilan Pidana. Widya Pajajaran: Bandung. 2009. HIm.28

36 Ibid.

37 J.W. La Patra dalam ibid. HIm. 2

38 Moeljanto. Asas-Asas Hukum Pidana. Rineka Cipta:Jakarta. 1993. HIm. 1
} 
f) Menentukan upaya hukum yang dapat diperlukan terhadap putusan yang diambil hakim;

g) Putusan yang pada akhirnya diambil berupa pidana atau tindak untuk dilaksanakan.

Salah satu landasan dalam penyelenggaraan peradilan pidana adalah Kitab Undang-Undang Hukum Acara Pidana (KUHAP). KUHAP mengatur cara-cara bagaimana negara menggunakan haknya untuk melakukan penghukuman dalam perkaraperkara yang terjadi. Hukum Acara Pidana merupakan suatu sistem kaidah norma yang diberlakukan negara dalam hal ini kekuasaan kehakiman untuk melaksanakan hukum pidana. Jadi fungsi hukum acara pidana untuk memberikan penetapan hukum terhadap seseorang tentang dipersalahkan atau tidak dan tentang penjatuhan pidana tertentu kepadanya. ${ }^{39}$

Wirjono Pradjodikoro, mengemukakan bahwa hukum acara pidana adalah acarabagaimana suatu badan hukum menuntut seseorang, cara mengambil suatu putusan dan cara melaksanakan suatu putusan pengadilan dan menjalankan suatu hukum pidana. ${ }^{40}$

Osman Simanjuntak, mengemukakan bahwa acara pidana secara umum dapat dikatakan sebagai himpunan ketentuan yang mengatur bagaimana melaksanakan hukum pidana material guna menjamin ketertiban dan ketentraman masyarakat guna mewujudakan keadilan dan kebenaran. ${ }^{41}$

Aparat penegak hukum dalam melaksanakan tugasnya harus melihat dan melaksanakan rumusan KUHAP sebagai satu kesatuan integral dengan seluruh motivasi KUHAP mulai dari landasan filosofis, landasan konstitional dan UU Kekuasaan Kehakiman serta landasan tujuan yang digariskan dalam bagian konsiderans KUHAP. Landasan filosofi KUHAP dapat dilihat dalam huruf a konsiderannya yaitu Pancasila terutama sila pertama dan sila kedua. Jika mengacu pada nilai-nilai pancasila maka KUHAP mengakui bahwa setiap pejabat aparat penegak hukum maupun tersangka/terdakwa adalah: ${ }^{42}$

a) Manusia yang dependen kepada Tuhan. Semua manusia diciptakan oleh Tuhan dan kelahirannya ke permukaan bumi adalah karena kehendak Tuhan, oleh karena itu tidak boleh ada perbedaan asasi di antara sesama manusia, manusia sama-sama mengembangkan dan mempertahankan kodrat, harkat dan martabatnya sebagai manusia ciptaan Tuhan dan manusia memiliki hak kemanusiaan yang harus dilindungi tanpak kecuali.

b) Fungsi dan tugas apapun yang dilaksanakan oleh manusia hanya semata-mata dalam lingkup menunaikan amanat dari Tuhan yang maha esa.

c) Fungsi pengabdian pada kehendak Tuhan diwujudkan dengan menempatkan setiap manusia sebagai hamba Tuhan yang memiliki harkat martabat kemanusiaan yang harus dilindungi serta menghargai hak setiap manusia untuk mempertahankan kehormatan dan martabatnya.

Para penegak hukum harus mampu untuk berani dan menegakkan isyarat keadilan yang konsisten dengan konsep keadilan Tuhan untuk diwujudkan dalam

\footnotetext{
${ }^{39}$ Djoko Prakoso. Alat Bukti dan Kekuatan Pembuktian dalam Proses Pidana. Liberty: Yogyakarta.1988. HIm.1

40 Wirjono Pradjodikoro. Hukum Acara Pidana Di Indonesia. Sumur : Bandung. 1977. HIm. 43

41 Osman Simanjuntak. Teknik Penuntutan dan Upaya Hukum. Kejaksaan Agung RI. Jakarta.1994. HIm3.

42 Muladi. Lembaga Pidana Bersyarat. P.T. Alumni: Bandung 2004, HIm. 11
} 
penegakan hukum. Hal ini pulalah yang melandasi sehingga setiap putusan harus berkepala "Demi Keadilan Berdasarkan Ketuhahan yang Maha Esa" sebagaimana ditegaskan dalam Pasal 197 ayat (1) KUHAP. Oleh karena itu, suatu keadilan harus memiliki dimensi pertanggung jawaban kepada hukum, kepada diri sendiri, kepada masyarakat, dan kepada Tuhan yang Maha Esa.

Cita penegakan hukum acara pidana juga menitik beratkan pada cita kemanusiaan sehingga setiap manusia apakah tersangka atau terdakwa maupun saksi harus diperlakukan sebagai manusia yang mempunyai harkat martabat dan diperlukan secara manusiawi dan beradab. Dengan landasan kemanusiaan ini maka diharapkan terciptanya suatu penegakan hukum yang luhur dan berbudi yang menempatkan kedudukan aparat penegak hukum sebagai pengendali hukum demi mempertahankan perlindungan ketertiban masyarakat pada satu pihak dan menempatkan kedudukan tersangka/terdakwa sebagai subjek hukum yang berhak mempertahankan derajat dan mertabatnya. ${ }^{43}$

Kitab Undang-Undang Hukum Acara Pidana merupakan pembaharuan hukum acara pidana, yang memuat hak-hak yang sebelumnya tidak dikenal dalam HIR. Untuk mencapai tujuan pembinaan aparat hukum maka tujuan dari KUHAP dikemukakan sebagai berikut: 44

a) Meningkatkan pembinaan ketertiban aparat penegak hukum sesuai dengan fungsi dan wewenang masing-masing;

b) Meningkatkan pembinanan profesionalisme;

c) Pembinaan dan peningkatan sikap mental;

d) Menegakkan hukum dan keadilan;

e) Melindungi harkat dan martabat manusia;

f) Menegakkan ketertiban dan kepastian hukum.

.Muladi dan Barda Nawawi Arief, menyimpulkan bahwa pidana mengandung unsur-unsur atau ciri-ciri sebagai berikut :

a) Pidana itu pada hakekatnya merupakan suatu pengenaan penderitaan atau nestapa atau akibat-akibat lain yang tidak menyenangkan;

b) Pidana itu diberikan dengan sengaja oleh orang atau badan yang mempunyai kekuasaan (oleh yang berwewenang);

c) Pidana itu dikenakan kepada seseorang yang telah melakukan tindak pidana menurut undang-undang. ${ }^{45}$

Sudarto, mengemukakan bahwa penghukuman berasal dari kata dasar hukum, sehingga dapat diartikan sebagai menetapkan hukum atau memutuskan tentang hukumanya (berschen) menetapkan hukum untuk suatu peristiwa itu tidak hanya menyangkut hukum pidana saja, akan tetapi juga hukum perdata. Oleh karena itu maka tulisan ini berkisar pada hukum pidana, maka istilah tersebut harus disempitkan artinya yaitu penghukuman dalam perkara pidana, yang kerap kali bersinonim dengan pemidanaan atau pemberian atau penjatuhan pidana oleh hakim. ${ }^{46}$

\footnotetext{
${ }^{43}$ Hermien Hadiati Koeswadji. Perkembangan Macam-Macam Pidana dalam Rangka Pembangunan Hukum Pidana. PT. Citra Aditya Bakti: Bandung 1995. HIm. 11-12

${ }^{44}$ Surastini Fitriasih. Perlindungan Saksi dan Korban Sebagai Saranan Menuju Proses Peradilan (Pidana) Yang Jujur dan adil.Makala www. Pemantau Peradilan com.

45 Muladi dan Barda Nawawi Arief. Teori-teori dan Kebijakan Pidana. Alumni :Bandung.1992. HIm 158.

46 Sudarto. Hukum dan Hukum Pidana. Alumni. Bandung, HIm. 36
} 
M. Sholehuddin, mengemukakan bahwa tujuan pemidanaan harus sesuai dengan politik hukum pidana dimana harus diarahkan kepada perlindungan masyarakat dari kesejahteraan serta keseimbangan dan keselarasan hidup dengan memperhatikan kepentingan masyarakat/negara, korban, dan pelaku. ${ }^{47}$

yaitu :

Sifat-sifat dari unsur pidana berdasarkan atas tujuan pemidanaan tersebut,

a) Kemanusiaan, dalam arti bahwa pemidanaan tersebut menjunjung tinggi harkat martabat seseorang.

b) Edukatif, dalam artian bahwa pemidanaan itu mampu membuat orang sadar sepenuhnya atas perbuatan yang dilakukan dan menyebabkan ia mempunyai sikap jiwa yang positif dan konstruktif bagi usaha penanggulangan kejahatan.

c) Keadilan, dalam artian bahwa pemidanaan tersebut dirasakan adil (baik oleh terhukum maupun oleh korban ataupun masyarakat).

Muladi mengemukakan pula pandangannya bahwa tujuan pemidanaan haruslah bersifat integratif, yaitu : ${ }^{48}$

a) Perlindungan masyarakat;

b) Memelihara solidaritas masyarakat;

c) Pencegahan (umum dan khusus);

d) Pengimbalan/pengimbangan.

\section{PEMBAHASAN}

\section{Aparat Penegak Hukum}

Sebagaimana disebutkan bahwa Aparat Pengak Hukum harus memiliki kemampuan dan keberanian didalam menegakkan keadilan dalam setiap pengambilan keputusan, hal ini pulalah yang melandasi sehingga setiap putusan harus didahului dengan kalimat pendek tapi mengandung arti sangat berat untuk dipertanggung jawabkan kepada diri sendiri, kepada masyarakat dan kepada Tuhan yang Maha Esa yaitu "DEMI KEADILAN BERDASARKAN KETUHANAN YANG MAHA ESA"

Dari gambaran tersebut penulis telah melakukan telaah wawancara terhadap sejumlah informan atau responden didalam penelitian ini yang dianggap memiliki peran yang sangat menentukan bagaimana proses perlindungan korban penganiayaan yang terjadi di Kota Tidore Kepulauan. Telaah wawancara ini di mulai tahap penyidikan oleh pihak kepolisian, pemeriksaan oleh hakim dan tahap pemeriksaan oleh pengadilan dan selanjutnya terhadap 4 korban penganiayaan sebagai informan kunci dalam penelitian ini.

a. Penerapan Perlindungan Korban pada Tahap Penyidikan oleh Kepolisian.

Tahap pertama dalam penanganan tindak pidana adalah tahapan lembaga kepolisian. Hasil wawancara penulis kepada Kasat Reskrim

\footnotetext{
47 Sholehuddin. M. Sistem Saksi dalam Hukum Pidana. PT. Raja Grafindo Persada. Jakarta. 2004.HIm.59

48 Muladi. Lembaga Pidana Bersyarat. Alumni : Bandung, HIm. 11
} 
PolresTidore Kepulauan ibu Anita Ratna Yulianto pada tanggal 2 juli 2015 mengemukakan bahwa :49

Perlindungan yang harus diberikan oleh kepolisian kepada korban cakupannya lebih luas jika dibandingkan dengan perlindungan yang diberikan oleh pihakpihak terkait lainnya, antara lain harus :

a. Mengamankan korban dari ancaman dan tindakan kekerasan lebih lanjut dari tersangka/pelaku

b. Merujuk/mengirimkan korban ke Pusat Pelayanan Terpadu (PPT) atau rumah sakit terdekat;

c. Mengantar korban ke rumah sakit untuk berobat dan meminta visum et repertum;

d. Segera memproses tersangka dan melakukan penahanan;

e. Menjamin keamanan dan keselamatan korban;

f. Segera menghubungi berbagai pihak untuk mendampingi korban

Selanjutnya Maslam Adjam selaku penyidik Polres Kota Tidore Kepulauan, memberikan keterangan kepada penulis bahwa :50

Selain keterangan yang disampaikan oleh Kasad Reskrim, beliau menambahkan bahwa apabila seorang korban merasa tidak nyaman atas keselamatan dirinya, keluarga maupun hartanya baik dari pelaku maupun dari masyarakat maka dalam hal ini pihak kepolisian wajib memberikan perlindungan terhadap korban dengan menyurat ke Lembaga Perlindungan Saksi dan Korban (LPSK), namun tersebut belum perna dilakukan khususnya di Kota Tidore Kepulauan. Selain itu apabila anak yang menjadi korban dalam penganiayaan maka langkah perlindungan yang diberikan meminta kepada Lembaga Sosial Profesional dalam hal ini Dinas Sosial Tenaga Kerja dan Transmigrasi untuk melakukan penelitian tentang kondisi psikologi maupun hal-hal lain yang berhubungan dengan masalah yang dialami anak tersebut.

Dari hasil wawancara tersebut peneliti menumukan beberapa ketentuan perlindungan saksi dan korban belum terimplentasi dengan maksimal, karena dari 4 korban penganiayaan yang menjadi sampel dalam penelitian semuanya menganggap bahwa pihak kepolisian belum memberikan jaminan keamanan dan bahkan belum perna ada pihak yang dihubungi oleh pihak kepolisian untuk mendampingi korban.

\section{b. Penerapan Perlindungan Korban pada Tahap Pemeriksaan oleh Hakim}

Lembaga Kejaksaan dengan Undang-Undang Nomor 16 Tahun 2004 telah diberikan kewenangan untuk melaksanakan kekuasaan Negara dibidang penuntutan. Kejaksaan memiliki peran yang sangat penting dalam proses

\footnotetext{
49 Wawancara Anita Ratna Yulianto selaku Kasat Reskrim POLRES Kota Tidore Kepulauan, tanggal 2 Juli 2015

50 Wawancara Maslam Adjam selaku Penyidik POLRES Kota Tidore Kepulauan, tanggal 7 Juli 2015
} 
penegakan hukum pidana, karena dapat tidaknya perkara pidana masuk ke pengadilan adalah tergantung sepenuhnya oleh Kejaksaan (penuntut umum).

Di dalam Pasal 2 ayat (3) Undang-Undang 16 Tahun 2004 dinyatakan bahwa kekuasaan kejaksaan dilakukan secara merdeka. Sebagaimana diketahui bahwa Undang-Undang Nomor 8 Tahun 1981, tentang Hukum Acara Pidana menganut sistem peradilan pidana yang mengutamakan perlindungan hak-hak asasi manusia, namun apabila ketentuan-ketentuan mengenai hal itu diperhatikan secara lebih mendalam, ternyata hanya hak-hak tersangka/terdakwa yang banyak ditonjolkan sedangkan hak-hak dari korban penganiayaan sangat sedikit diatur. Sejalan dengan asas tersebut masyarakat khususnya media massa lebih banyak monyoroti mengenai hak-hak tersangka/terdakwa dari pada mempermasalahkan mengenai Perlindungan terhadap Korban Penganiayaan.

Sehubungan dengan itu penulis melakukan wawancara dengan Matulessy (Kasipidum) Kejaksaaan Negeri Soasio pada tanggal 29 Juni 2015 mengemukakan bahwa : 51

1. Sejak tahap penuntutan secara moral pihak kejaksaan harus memberitahukan apa yang menjadi hak-hak korban, salah satu haknya adalah meminta ganti rugi.

2. Sejak perkara dilimpahkan kepengadilan, Jaksa wajib membangun komunikasi dengan saksi terutama saksi korban berkaitan jadwal persidangan karena dalam KUHAP saksi yang pertama di periksa adalah saksi korban.

3. Selanjutnya pihak kejaksaan memberikan jaminan kepada korban dalam bentuk penyampaian memenuhi bahwa korban wajib hadir di persidangan dan dengan bebas tanpa tekanan dari pihak manapun termasuk pihak pelaku dalam memberikan kesaksian di pengadilan.

4. Pengajuan rencana tuntutan pidana terhadap pelaku harus memenuhi rasa keadilan dari korban dan masyarakat.

Selanjutnya wawancara tanggal 30 juni 2015 pada Meliyan Marantika selaku Kepala Seksi Intelejen Kejaksaan Soasio mengatakan bahwa : 52

Dalam hal perlindungan hukum secara pisik terhadap korban tidak diatur dalam undang-undang yang mewajibkan jaksa untuk melakukan perlindungan fisik terhadap korban namun secara moral hanya dapat memberikan informasi sebagaimana apa yang ditanyakan oleh korban. Tetapi jika korban tersebut adalah akibat kekerasan dalam rumah tangga maka dalam hal ini jaksa wajib untuk memberikan perlindungan 1 × 24 jam sebagaimana diatur dalam Pasal 10 Undang-Undang KDRT. Dimana seorang korban yang merasa dirinya terancam maka dari tingkat penuntutan jaksa wajib memberikan perlindungan terhadap korban berdasarkan penetapan perintah perlindungan dari pengadilan (hakim)

\footnotetext{
51 Wawancara Matulessy selaku Kepala Seksi Satuan Pidana Umum (Kaspidum) Kejaksaan Negeri Soasio, tanggal 29 Juni 2015

52 Wawancara Marantika selaku Kepala Seksi Intelejen Kejaksaan Negeri Soasio, tanggal 30 Juni 2015
} 
Dari hasil wawancara di atas penulis menemukan beberapa kelemahan atau kekurangan dari pihak kejaksaaan dalam hal memberikan hukum terhadap korban penganiayaan, hakim dalam hal ini hanya memberikan informasi apabila ada pertanyaan dari korban tentang proses kasus yang dialami, jaksa tidak menyampaikan apa yang menjadi hak korban dan juga tidak memperahatikan secara maksimal tentang prosedur penggabungan ganti kurugian dalam tuntutan pidana, juga alasan pihak kejaksaan untuk tidak menyampaikan hal tersebut karena tidak ada satupun pasal yang mewajibkan jaksa untuk memberitahukan tentang penggabungan gugatan ganti kerugian. Jelas penggabungan untuk gugutan ganti rugi pada Pengadilan Negeri Soasio belum pernah ada. Sedangkan didalam KUHAP disebutkan secara jelas adanya penggabungan perkara tentang gugatan ganti kerugian yang dapat diajukan oleh korban sebelum pembacaan penuntutan oleh jaksa didalam proses persidangan di pengadilan, hal ini sangat penting bagi korban untuk diketahui.

\section{c. Penerapan Perlindungan Korban pada Tahap Pemeriksaan oleh Pengadilan.}

Hakim dalam persidangan kasus tindak pidana memiliki peran yang sangat penting karena di tangan hakim akan ditentukan putusan mengenai suatu tindak pidana. Dalam wawancara penulis tangal 5 Juli 2015 dengan Kadar Noh Hakim Pengadilan Negeri Soasio Kota Tidore Kepulauan, dikemukakan beberapa bentuk perlindungan terhadap korban penganiayaan yaitu : ${ }^{53}$

1. Apabila korban merasa tidak aman atau nyaman dalam memberikan kesaksian di pengadilan maka korban dapat mengajukan permohonan untuk perlindungan/keamanan diri maupun keluarganya kepada ketua Pengadilan Negeri Soasio;

2. Terkait dengan pengajuan permohonan korban. Ketua Pengadilan Negeri Soasio menyurat kepada pihak kepolisian untuk melakukan pengamanan terhadap diri korban

3. Pihak kepolisian menunjuk/menugaskan beberapa anggota untuk melakukan pengamanan terhadap diri korban dan keluarga.

4. Hakim dalam memberikan pertanyaan di persidangan tidak bertujuan untuk memojokkan korban, hanya diminta untuk menceritakan kronologis peristiwa yang telah dialaminya;

5. Apabila korban dalam persidangan merasa psikologi terganggu ketika berhadapan langsung dengan terdakwa maka hakim ketua meminta terdakwa untuk meninggalkan ruangan sidang untuk sementara waktu tahapan pemeriksaan saksi korban dalam persidangan.

6. Dalam hal ganti rugi, biaya pengobatan korban akibat perbuatan tindak pidana penganiayaan yang dilakukan oleh terdakwa,majelis hakim dapat mengabulkan apabila ada permohonan dari korban sebelum tuntutan di bacakan oleh jaksa yang biasa dilakukan dalam penggabungan perkara.

53 Wawancara Kadar Noh selaku Hakim Pengadilan Negeri Soasio, tanggal 5 Juli 2015 
Selanjutnya hasil wawancara dari Satriyani Alwi. Tanggal 8 Juli 2015 selaku Hakim Pengadilan Negeri Soasio mengatakan bahwa : ${ }^{54}$

Penggabungan perkara tentang ganti kerugian terhadap korban penganiayaan selama ini belum pernah terjadi. Adapun ganti rugi yang diberikan oleh pelaku terhadap korban sebelum perkara sampai dipersidangan itu hanya menjadikan pertimbangan alasan yang meringankan dalam penjatuhan pidana terhadap terdakwa.

Dari hasil wawancara di atas penulis melihat Pandangan di atas menunjukkan bahwa setiap tahapan penanganan perkara pidana, perlindungan korban harus mendapatkan tempat karena bagaimana pun korban memegang peran penting dalam suatu peradilan pidana, selain itu juga merupakan bagian dari penegakan hak-hak asasi manusia. Pemahaman mengenai perlindungan hukum tehadap korban merupakan bagian penting yang perlu diketahui karena pemahaman tersebut akan mendukung pelaksanaan tugas aparat penegak hukum, pelaksanaan kontrol dari masyarakat serta pendidikan bagi masyarakat baik masyarakat biasa maupun korban penganiayaan.

\section{d. Hasil Wawancara Terhadap Korban Penganiayaan.}

Korban didalam menjalani proses hukum mulai dari kepolisian, kejaksaan dan sampai ditingkat pengadilan, beragam pendapat yang telah dikemukakan oleh korban terhadap penulis tentang hak-hak korban sebagaimana tertuang di dalam Pasal 1 angka 2 Undang-Undang-Undang Nomor 13 Tahun 2006 tentang perlindungan Saksi dan Korban.

Peneliti mengambil 4 sampel kasus korban penganiayaan yang sudah mempunyai putusan hukum yang tetap antara lain :

1. Rahman Djaber Alias Mances

2. Asrul Marsaoly Alias Acun

3. Haryati Konoras Alias Yati

4. Irma Wahidin Alias Ine

Untuk mengetahui bagaimana perlindungan hukum terhadap ke 4 korban penganiayaan sekaligus sebagai sampel, berikut ini penulis akan mengemukakan hasil wawancara terstruktur atau melalui intrumen penelitian (kuesioner) sebagaimana tertuang didalam tabel berikut ini :

\section{Tabel 2}

Jawaban responden atau korban tentang Perlindungan dan hak-hak korban penganiayaan

\begin{tabular}{|c|c|c|c|c|}
\hline NO & INDIKATOR DAN JAWABAN & F & \% & KET. \\
\hline 1 & $\begin{array}{l}\text { Memperoleh perlindungan atas keamanan } \\
\text { pribadi, keluarga dan harta bendanya, serta }\end{array}$ & & & \\
\hline
\end{tabular}

\footnotetext{
${ }^{54}$ Wawancara Satriyanti Alwi selaku Hakim Pengadilan Negeri Soasio, tanggal 8 Juli 2016
} 


\begin{tabular}{|c|c|c|c|c|}
\hline & $\begin{array}{l}\text { bebas dari ancaman yang berkenaan dengan } \\
\text { kesaksian yang akan, sedang atau telah } \\
\text { diberikan? } \\
\text { a. Ya } \\
\text { b. Tidak }\end{array}$ & $\begin{array}{l}3 \\
1\end{array}$ & $\begin{array}{l}75 \\
25\end{array}$ & \\
\hline 2 & $\begin{array}{l}\text { Ikut serta dalam proses memilih dan } \\
\text { menentukan bentuk perlindungan dan } \\
\text { dukungan keamanan } \\
\text { a. Ya } \\
\text { b. Tidak }\end{array}$ & $\begin{array}{l}- \\
4\end{array}$ & $\begin{array}{c}- \\
100\end{array}$ & \\
\hline 3 & $\begin{array}{l}\text { Memberikan keterangan tanpa tekanan } \\
\text { a. Ya } \\
\text { b. Tidak }\end{array}$ & $\begin{array}{l}2 \\
2\end{array}$ & $\begin{array}{l}50 \\
50\end{array}$ & \\
\hline 4 & $\begin{array}{l}\text { Mendapat penerjemah } \\
\text { a. Ya } \\
\text { b. Tidak }\end{array}$ & $\begin{array}{l}- \\
4\end{array}$ & $\begin{array}{c}- \\
100 \\
\end{array}$ & \\
\hline 5 & $\begin{array}{l}\text { Bebas dari pertanyaan yang menjerat } \\
\text { a. Ya } \\
\text { b. Tidak }\end{array}$ & $\begin{array}{l}4 \\
-\end{array}$ & $\begin{array}{c}100 \\
-\end{array}$ & \\
\hline 6 & $\begin{array}{l}\text { Mendapatkan informasi mengenai } \\
\text { perkembangan kasus } \\
\text { a. Ya } \\
\text { b. Tidak }\end{array}$ & $\begin{array}{l}4 \\
-\end{array}$ & $\begin{array}{c}100 \\
-\end{array}$ & \\
\hline 7 & $\begin{array}{l}\text { Mendapatkan informasi mengenai putusan } \\
\text { pengadilan } \\
\text { a. Ya } \\
\text { b. Tidak }\end{array}$ & - & $\begin{array}{c}- \\
100\end{array}$ & $N=4$ \\
\hline 8 & $\begin{array}{l}\text { Mengetahui dalam hal terpidana dibebaskan } \\
\text { a. Ya } \\
\text { b. Tidak }\end{array}$ & $\begin{array}{l}1 \\
3\end{array}$ & $\begin{array}{l}25 \\
75\end{array}$ & \\
\hline 9 & $\begin{array}{l}\text { Mendapatkan informasi baru } \\
\text { a. Ya } \\
\text { b. Tidak }\end{array}$ & - & $\begin{array}{c}- \\
100\end{array}$ & \\
\hline 10 & $\begin{array}{l}\text { Mendapatkan tempat kediaman baru } \\
\text { a. Ya } \\
\text { b. Tidak }\end{array}$ & - & $\begin{array}{c}- \\
100\end{array}$ & \\
\hline 11 & $\begin{array}{l}\text { Memperoleh pergantian biaya transfortasi } \\
\text { sesuai dengan kebutuhan } \\
\text { a. Ya } \\
\text { b. Tidak }\end{array}$ & - & $\begin{array}{c}- \\
100\end{array}$ & \\
\hline 12 & $\begin{array}{l}\text { Mendapat nasehat hukum } \\
\text { a. Ya }\end{array}$ & 4 & 100 & \\
\hline
\end{tabular}




\begin{tabular}{|c|c|c|c|}
\hline & b. Tidak & - & - \\
\hline 13 & $\begin{array}{l}\text { Memperoleh bantuan biaya hidup sementara } \\
\text { sampai batas waktu perlindungan berakhir } \\
\text { a. Ya } \\
\text { b. Tidak }\end{array}$ & - & $\begin{array}{c}- \\
100\end{array}$ \\
\hline 14 & $\begin{array}{l}\text { Dalam hal terhadap korban pelanggaran Hak } \\
\text { Asasi Manusia (HAM) berat selain hal di atas, } \\
\text { juga berhak pula untuk mendapatkan bantuan } \\
\text { medis dan bantuan rehabilitasi psiko-sosial } \\
\text { a. Ya } \\
\text { b. Tidak }\end{array}$ & $\begin{array}{l}- \\
4\end{array}$ & $\begin{array}{c}- \\
100\end{array}$ \\
\hline
\end{tabular}

Sumber : Hasil olahan data primer, 2015

Penjelasan tabel :

a. Perlindungan rasa aman korban sebagai saksi dan bebas dari ancaman, $75 \%$ atau 3 responden memberikan jawab Ya sedangkan $25 \%$ atau 1 responden memberikan jawaban tidak

b. Hak ke 5, 6, serta ke 12. Responden mendapatkan hak penuh didalam perlindungan hukum atau $100 \%$ responden menjawab Ya.

c. Sedangkan hak korban yang ke 2, 4, 7, 9, 10, 11, 13, 14. responden memberikan jawaban tidak mendapat perlindungan hukum atau $100 \%$ atau 4 orang memberikan jawaban tidak.

\section{Mediasi Penal}

Dalam perpektif ini penulis memberikan analisa dengan pendekatan Restorative Justice, sebab teori keadilan restorative menempatkan sejumlah nilai yang lebih tinggi pada keterlibatan langsung oleh pihak-pihak yang terkait, korban berfungsi sebagai elemen control. Pelanggar didorong untuk menerima tanggungjawab sebagai tahapan yang penting dalam memperbaiki kerugian yang disebabkan oleh kejahatan dan dalam membangun sistem nilai tanggung jawab sosial. Keterlibatan masyarakat secara aktif memperkuat masyarakat itu sendiri dan menegakkan nilai yang tanggap dan peduli kepada yang lain.

Restorative Justice adalah pendekatan untuk membuat pemidanaan dan pelembagaan menjadi sesuai dengan keadilan. Restorative Justice dibangun atas dasar nilai-nilai tradisional komunitas yang positif dan saksi-saksi yang dilaksanakan menghargai hak asasi manusia (HAM). Prinsip-prinsip Restorative Justice adalah membuat pelaku bertanggung jawab untuk membuktikan kapasitasnya dan kualitasnya sebaik dia mengatasi rasa bersalahnya dengan cara yang kontruktif, melibatkan korban, orang tua, keluarga, sekolah atau teman bermainnya, membuat forum kerja sama, juga dalam masalah yang berhubungan dengan kejahatan untuk mengatasinya. Hal ini berbeda dengan konsep keadilan yang kita kenal dalam system hukum pidana Indonesia yang bersifat Restributive Justice. Konsep Restorative Justice merupakan konsep yang didasarkan pada tujuan hukum sebagai upaya dalam menyelesaikan konflik dan mendamaikan antara pelaku dan korban kejahatan. Pidana penjara bukanlah satu-satunya pidana 
yang dapat dijatuhkan paada pelaku kejahatan, tetapi pemulihan kerugian dan penderitaan yang dialami korban akibat kejahatanlah yang harus diutamakan. Kewajiban merestorasi akibat kejahatan dalam bentuk restitusi dan kompensasi serta rekonsiliasi dan penyantuan sosial merupakan bentuk pidana dalam konsep Restorative Justice. Munculnya konsep Restorative Justice pada dasarnya diharapkan agar dapat memberikan dan memenuhi rasa tanggung jawab sosial pada pelaku dan mencegah stigmatisasi pelaku dimasa yang akan datang.

Proses restorative justice pada dasarnya merupakan upaya pengalihan dari proses peradilan pidana menuju penyelesaian secara musyawarah atau mediasi yang pada dasarnya merupakan jiwa dari bangsa Indonesia, untuk menyelesaikan permasalahan dengan cara kekeluargaan untuk mufakat.

Penerapan Restorative Justice juga terlihat pada beberapa kebijakan penegak hukum, diantaranya :

a. Surat Edaran Mahkamah Agung (SEMA) No. 6 Tahun 1959, menyebutkan bahwa persidangan anak harus dilakukan secara tertutup.

b. Surat Edaran Mahkama Agung (SEMA) No. 6 Tahun 1987, tanggal 16 November 1987 tentang Tata Tertib Sidang Anak.

c. Surat Edaran Jaksa Agung RI SE-002/j.a/4/1989 tentang Penuntutan terhadap anak.

d. Yurisprudensi Mahkamah Agung RI Nomor $1644 \mathrm{~K} / \mathrm{Pid} / 1988$ tanggal 15 Mei 1991 dimana dalam ratio decidendi putusan disebutkan bahwa apabila seseorang melanggar hokum adat kemudian Kepala dan Para Pemuka Adat memberikan reaksi adat (saksi adat) maka yang bersangkutan tidak dapat diajukan lagi (untuk kedua kalinya) sebagai terdakwa dalam persidangan Badan Peradilan Negara (Pengadilan Negeri) dengan dakwaan yang sama melenggar hokum ada dan dijatuhkan pidana penjara menurut ketentuan KUHP Pidana (Pasal 5 ayat (3) sub b UU drt Nomor 1 Tahun 1951 sehingga dalam keadaan demikian pelimpahan berkas perkara serta tuntutan Kejaksaan di Pengadilan Negeri harus dinyatakan tidak dapat diterima (nietontvakelijk Verklaard)

e. Surat Keputusan bersama Ketua Mahkamah Agung RI, Jaksa Agung RI, Kepala Kepolisian Negara RI, Meteri Hukum dan HAM RI, Menteri Sosial RI, Menteri Pemberdayaan Perempuan dan Perlindungan Anak RI, Nomor 166/KMA/SKB/XII/2009 Tahun 2009, No. 10/PRS-2/KPTS/2009, No. 02/Men.PP dan PA/XII/2009 tanggal 22 Desember 2009 tentang Penanganan Anak yang Berhadapan dengan hokum.

f. Surat Kapolri No. Pol : B/3022/XII/2009/SDEOPS tanggal 14 Desember 2009 tentang Penanganan Kasus Melalui Alternatif Dispute Resolution (ADRT)

g. Peraturan Kepala Kepolisian Negara Republik Indonesia Nomor 7 Tahun 2008 Tentang Pedoman Dasar Strategi dan Implementasinya Pemolisian Masyarakat Dalam Penyelenggaraan Tugas Polri.

h. Undang-Undang Nomor II Tahun 2012 Tentang Sistem Peradilan Anak

i. Undang-Undang Nomor 12 Tahun 1995 tentang Pemasyarakatan 


\section{Putusan Pengadilan Negeri Soasio}

Jumlah korban penganiayaan yang telah diputus oleh Pengadilan Negeri Soasio tahun 2014 sebanyak 41 kasus penganiayaan dengan rincian 17 penganiayaan biasa, 20 penganiayaan ringan dan 4 penganiayaan berat. Adapun kasus penganiayaan yang dimaksud dapat dilihat pada tabel berikut ini.

Tabel 3

Tindak Pidana Penganiayaan Yang Telah Mempunyai Kekuatan Hukum Tetap Pada Pengadilan Negeri Soasio Tahun 2014

\begin{tabular}{|c|c|c|c|}
\hline No & No. Perkara & Nama Korban & $\begin{array}{l}\text { Umur } \\
\text { (thn) }\end{array}$ \\
\hline 1 & 02/Pid.B/2014/PN.SOS & Rusli Rajak alias uli & 25 \\
\hline 2 & 03/Pid.B/2014/PN.SOS & Abdullah Sabtu alais dulla & 53 \\
\hline 3 & 05/Pid.B/2014/PN.SOS & Yunus Mahmud alias jafar & 28 \\
\hline 4 & 08/Pid.B/2014/PN.SOS & Haji Abdullah & 23 \\
\hline 5 & 012/Pid.B/2014/PN.SOS & Rahman Jaber & 22 \\
\hline 6 & 14/Pid.B/2014/PN.SOS & Hariyati Konoras & 21 \\
\hline 7 & 17/Pid.B/2014/PN.SOS & 'Labore Safar & 26 \\
\hline 8 & 18/Pid.B/2014/PN.SOS & Ishak Faisal & 3 \\
\hline 9 & 19/Pid.B/2014/PN.SOS & Asrul Marsaoly & 54 \\
\hline 10 & 23/Pid.B/2014/PN.SOS & Dicky & 39 \\
\hline 11 & 27/Pid.B/2014/PN.SOS & Rusli Lanas & 40 \\
\hline 12 & 31/Pid.B/2014/PN.SOS & Johannes Khairun & 44 \\
\hline 13 & 32/Pid.B/2014/PN.SOS & Harlina Ibrahim & 20 \\
\hline 14 & 38/Pid.B/2014/PN.SOS & Irma Wahidin & 29 \\
\hline 15 & 41/Pid.B/2014/PN.SOS & Luviyaty & 26 \\
\hline 16 & 48/Pid.B/2014/PN.SOS & Perdius Karianga & 38 \\
\hline 17 & 49/Pid.B/2014/PN.SOS & Muhammad Dasrunda & 39 \\
\hline 18 & 103/Pid.B/2014/PN.SOS & Asis Abdurrahamn & 41 \\
\hline 19 & 104/Pid.B/2014/PN.SOS & Malan Senen & 31 \\
\hline 20 & 107/Pid.B/2014/PN.SOS & Siti Nur Senen & 25 \\
\hline 21 & 109/Pid.B/2014/PN.SOS & Haris Ahmad & 23 \\
\hline 22 & 110/Pid.B/2014/PN.SOS & Domis Boli & 22 \\
\hline 23 & 111/Pid.B/2014/PN.SOS & Husain Ahmad & 27 \\
\hline 24 & 114/Pid.B/2014/PN.SOS & Syamsul Hasan & 23 \\
\hline 25 & 116/Pid.B/2014/PN.SOS & Malik Abd. Hamid & 20 \\
\hline 26 & 53/Pid.B/2014/PN.SOS & Rustam & 30 \\
\hline 27 & 54/Pid.B/2014/PN.SOS & Rusli Esa & 36 \\
\hline 28 & 56/Pid.B/2014/PN.SOS & Syamsuddin & 31 \\
\hline 29 & 57/Pid.B/2014/PN.SOS & Mujais Kiye & 37 \\
\hline 30 & 59/Pid.B/2014/PN.SOS & Adam Hi. Yunus & 30 \\
\hline 31 & 63/Pid.B/2014/PN.SOS & Nila Thaib & 19 \\
\hline 32 & 66/Pid.B/2014/PN.SOS & Muhammad A. Taran & 39 \\
\hline 33 & 75/Pid.B/2014/PN.SOS & Erwin Santen & 35 \\
\hline 34 & 76/Pid.B/2014/PN.SOS & Fahrus Rizki & 22 \\
\hline 35 & 81/Pid.B/2014/PN.SOS & Eprafat & 19 \\
\hline 36 & 85/Pid.B/2014/PN.SOS & Abdul Haris & 20 \\
\hline
\end{tabular}




\begin{tabular}{|l|l|l|l|}
\hline 37 & 86/Pid.B/2014/PN.SOS & Berna Toskon & 32 \\
38 & 88/Pid.B/2014/PN.SOS & Rinto Salim & 20 \\
39 & 89/Pid.B/2014/PN.SOS & Ismail & 30 \\
40 & 91/Pid.B/2014/PN.SOS & Muhdar Saleh & 25 \\
41 & 92/Pid.B/2014/PN.SOS & Dahlan Saman & 37 \\
\hline
\end{tabular}

Sumber data : Pengadilan Negeri Soasio, 2014

Tabel 4

Tindak Pidana Penganiayaan Biasa Yang Telah Mempunyai Kekuatan Hukum Tetap Pada Pengadilan Negeri Soasio Tahun 2014

\begin{tabular}{|c|c|c|c|}
\hline No & No. Perkara & Nama Korban & $\begin{array}{l}\text { Akibat yang } \\
\text { di timbulkan }\end{array}$ \\
\hline 1 & 05/Pid.B/2014/PN.SOS & Yunus Mahmud & Luka lecet \\
\hline 2 & 08/Pid.B/2014/PN.SOS & Haji Abdullah & Luka robek (bengkak) \\
\hline 3 & 13/Pid.B/2014/PN.SOS & Rahman Jaber & Luka robek \\
\hline 4 & 14/Pid.B/2014/PN.SOS & Hariyati Konoras & Sda \\
\hline 5 & 18/Pid.B/2014/PN.SOS & Ishak Faisal & Luka lecet \\
\hline 6 & 32/Pid.B/2014/PN.SOS & Harlina Ibrahim & Luka gores \\
\hline 7 & 53/Pid.B/2014/PN.SOS & Faisal Rustam & Luka gores \\
\hline 8 & 75/Pid.B/2014/PN.SOS & Erwin Santen & Luka bengkak \\
\hline 9 & 76/Pid.B/2014/PN.SOS & Fahrus Rizki & Luka \\
\hline 10 & 81/Pid.B/2014/PN.SOS & Eprafat & sda \\
\hline 11 & 85/Pid.B/2014/PN.SOS & Abdul Haris & sda \\
\hline 12 & 86/Pid.B/2014/PN.SOS & Berna Toskon & sda \\
\hline 13 & 88/Pid.B/2014/PN.SOS & Rinto Salim & sda \\
\hline 14 & 89/Pid.B/2014/PN.SOS & Ismail & sda \\
\hline 15 & 91/Pid.B/2014/PN.SOS & Muhdar Saleh & sda \\
\hline 16 & 92/Pid.B/2014/PN.SOS & Dahlan Saman & sda \\
\hline 17 & 114/Pid.B/2014/PNSOS & Syamsul Hasan & sda \\
\hline
\end{tabular}

Sumber data : Pengadilan Negeri Soasio, 2014

Tabel 5

Tindak Pidana Penganiayaan Ringan Yang Telah Mempuyai Kekuatan Hukum Tetap Pada Pengadilan Negeri Soasio Tahun 2014

\begin{tabular}{|c|l|l|c|}
\hline No & \multicolumn{1}{|c|}{ No. Perkara } & \multicolumn{1}{|c|}{ Nama Korban } & $\begin{array}{c}\text { Akibat yang } \\
\text { di timbulkan) }\end{array}$ \\
\hline 1 & $02 /$ Pid.B/2014/PN.SOS & Rusli Rajak alias uli & Bengkak \\
2 & $03 /$ Pid.B/2014/PN.SOS & Abdullah Sabtu & Sda \\
3 & $17 /$ Pid.B/2014/PN.SOS & 'Labore Safar & luka memar \\
4 & $19 /$ Pid.B/2014/PN.SOS & Asrul Marsaoly & luka bengkak \\
5 & $23 /$ Pid.B/2014/PN.SOS & Dicky & luka memar \\
6 & $38 /$ Pid.B/2014/PN.SOS & Irma Wahidin & bengkak \\
7 & $41 /$ Pid.B/2014/PN.SOS & Luviyaty & luka robek \\
8 & $48 /$ Pid.B/2014/PN.SOS & Perdius Karianga & luka bengkak \\
9 & $49 /$ Pid.B/2014/PN.SOS & Muhammad Dasrunda & memar \\
\hline
\end{tabular}




\begin{tabular}{|c|c|c|c|}
\hline 10 & 103/Pid.B/2014/PN.SOS & Asis Abdurrahamn & luka \\
\hline 11 & 104/Pid.B/2014/PN.SOS & Malan Senen & luka-luka \\
\hline 12 & 107/Pid.B/2014/PN.SOS & Siti Nur Senen & sda \\
\hline 13 & 109/Pid.B/2014/PN.SOS & Haris Ahmad & luka ringan \\
\hline 14 & 111/Pid.B/2014/PN.SOS & Husain Ahmad & luka-luka \\
\hline 15 & 54/Pid.B/2014/PN.SOS & Rusli Esa & sda \\
\hline 16 & 56/Pid.B/2014/PN.SOS & Syamsuddin & sda \\
\hline 17 & 57/Pid.B/2014/PN.SOS & Mujais Kiye & sda \\
\hline 18 & 59/Pid.B/2014/PN.SOS & Adam Hi. Yunus & sda \\
\hline 19 & 63/Pid.B/2014/PN.SOS & Nila Thaib & sda \\
\hline 20 & 66/Pid.B/2014/PN.SOS & Muhammad A. Taran & sda \\
\hline
\end{tabular}

Sumber data : Pengadilan Negeri Soasio, 2014

Tabel 6

Tindak Pidana Penganiayaan Berat Yang Telah Mempunyai Kekuatan Hukum Tetap Pada Pengadilan Negeri Soasio Tahun 2014

\begin{tabular}{|c|c|c|c|}
\hline No & No. Perkara & Nama Korban & $\begin{array}{l}\text { Akibat yang } \\
\text { di timbulkan }\end{array}$ \\
\hline $\begin{array}{l}1 \\
2 \\
3 \\
4\end{array}$ & $\begin{array}{l}\text { 27/Pid.B/2014/PN.SOS } \\
\text { 31/Pid.B/2014/PN.SOS } \\
\text { 110/Pid.B/2014/PN.SOS } \\
\text { 116/Pid.B/2014/PN.SOS }\end{array}$ & $\begin{array}{l}\text { Rusli Lanas } \\
\text { Johannes Khairun } \\
\text { Domis Boli } \\
\text { Malik Abd. Hamid } \\
\end{array}$ & $\begin{array}{l}\text { Luka berat } \\
\text { sda } \\
\text { sda } \\
\text { sda }\end{array}$ \\
\hline
\end{tabular}

Sumber data : Pengadilan Negeri Soasio, 2014

Berdasarkan tabel di atas menunjukkan bahwa korban mengalami luka berat yang mengakibatkan korban menderita sakit juga kerugian materi akibat penganiayaan yang dilakukan terdakwa maka di kategorikan tindak penganiayaan berat sebagaimana diatur dalam Pasal $353 \mathrm{KUHP}$.

Dari ke 3 tabel diatas (tabel 4,5,dan 6) tentang penggolongan tindak pidana penganiayaan, penulis melihat bahwa pada korban penganiayaan yang dapat meminta ganti kerugian menurut ketentuan Pasal 98 KUHAP adalah korban penganiayaan yang dapat membuktikan bahwa korban benar-benar menderita kerugian yang harus dibuktikan secara tertulis dan menyakinkan hakim yang memeriksa, mengadili perkara penganiayaan. Permintaan ganti kerugian harus diajukan harus diajukan sebelum tuntutan dibacakan oleh jaksa dan hakim dapat mengeluarkan penetapan tentang besarnya ganti kerugian yang dialami oleh korban penganiayaan.

Struktur hukum atau aparat merupakan bagian dari sistem hukum yang bergerak dalam satu mekanisme termasuk dalam komponen ini antara lain lembaga pembuat Undang-Undang, pengadilan dan lembaga yang diberi wewenang untuk menerapkan hukum serta lembaga yang diberi wewenang untuk melakukan penindakan terhadap pihak yang melanggar ketentuan hukum. Aparat penegak hukum menunjuk kepada pengertian mengenai institusi penegak hukum yang dimulai dari saksi, polisi, penasehat hukum, jaksa hakim dan petugaspetugas sipir pemasyarakatan. 
Dalam proses bekerjanya, aparatur penegak hukum dipengaruhi oleh 3 elemem penting yang sangat berpengaruh yaitu : (1) institusi penegak hukum beserta perangkat sarana dan prasarana pendukung serta mekanisme kerja kelembagaanya; (2) budaya kerja yang terkait dengan aparat termasuk faktor kesejahteraan; dan (3) perangkat peraturan yang mendukung baik kenerja kelembagaanya maupun yang mengatur materi hukum yang dijadikan standar kerja, baik hukum materilnya maupun hukum acaranya. Hal ini dapat dilihat dalam salah satu kasus yang mana aparat penegak hokum sangat lambat dalam memberikan perlindungan hokum terhadap korban penganiayaan pada tanggal 12 Agustus 2015 bernama Abd. Rahman Djuber yang melaporkan kasus penganiayaan terhadap diri korban yang mengalami luka tusukan dan luka robek yang cukup serius. Dalam penganannya sangat berlarut larut cukup lama karena pihak kepolisian beralasan banyaknya kasus-kasus yang masih bertumpuk yang harus diproses lebih awal. Hal ini bukan suatu yang dapat dijadikan alasan sebagai dasar bagi aparat kepolisian untuk tidak memperoses lebih cepat, selanjutnya korban menuturkan kepada penulis bahwa selama menjadi korban sangat banyak kerugian yang dialami terutama dalam proses penyembuhan, namun tidak sediktpun biaya yang diberikan oleh pelaku kejahatan sampai kasus tersebut di putus di pengadilan. Ini terlihat kurangnya pemahaman bagi aparat tentang perlindungan terhadap korban yang seharusnya pada tahap penuntutan oleh pihak kejaksaan mempertimbangkan untuk mencantumkan ganti kerugian dalam berkas perkara sebelum tuntutan di bacakan di pengadilan walaupun hal ini tidak dimintakan oleh korban.

Integritas aparat penegak hukum menjadi faktor utama dalam upaya mengimplemtasikan perlindungan hukum terhadap korban. Untuk memahami apa yang dimaksud dengan integritas maka penulis mengutif pengertian integritas dari Kamus Bahasa Besar Indonesia yaitu mutu, sifat atau keadaan yang menunjukkan kesatuan yang utuh sehingga memiliki potensi dan kemampuan yang memancarkan kewibawaan, kejujuran. Potensi dan kemampuan yang dimaksud dalam defenisi tersebut antara lain pengetahuan dan pemahaman aparat penegak hukum mengenai proses perlindungan hukum terhadap korban penganiayaan. Realitas saat ini menunjukkan bahwa aparat penegak hukum masih belum mampu untuk sepenuhnya memberikan suatu pemahaman yang baik tentang perlindungan hukum terhadap korban.

Pemahaman aparat penegak hukum merupakan faktor yang sangat penting dalam menilai efektifitas dalam perbandingan hukum terhadap korban penganiayaan karena mereka merupakan pihak yang berkaitan langsung dengan perlindungan terhadap korban. Pemahaman yang baik seharusnya di ikuti dengan pelaksanaan tugas yang baik, namun realitas kerap kali menunjukkan kenyataan sebaliknya sehingga hal ini menjadi suatu fenomena yang perlu untuk dipahami.

Penulis berpandangan bahwa pemahaman yang tidak diikuti dengan implementasi yang optimal menunjukkan adanya ketidaktaatan dan ketidak patuhan aparat penegak hukum dalam memberikan perlindungan hukum kepada korban penganiayaan. Disamping itu korban dalam hal ini juga kurang memahami mengenai perlindungan terhadap mereka, minimnya pemahaman akan menimbulkan suatu kondisi dimana pihak korban penganiayaan tidak mengetahui 
tindakan-tindakan yang dapat mereka lakukan untuk mewujudkan perlindungan terhadap diri mereka akibat kerugian yang dialami.

Pemahaman korban penganiayaan yang minim menyebabkan pula mereka tidak memahami bahwa mereka memiliki hak-hak untuk mendapatkan ganti rugi atau kompensasi akibat penganiayaan yang dilakukan pelaku terhadap diri meraka.

Pelaksanaan perlindungan hukum terhadap korban oleh aparat penegak hukum menjadi terhambat karena tidak optimalnya pengaturan perlindungan hukum terhadap korban, jadi meskipun aparat penegak hukum mengetahui bahwa korban perlu dilindungi, namun tanpa adanya payung hukum yang memadai, aparat penegak hukum tidak dapat optimal dalam memberikan perlindungan kepada para korban penganiayaan. Optimalisasi perlindungan hukum terhadap korban tidak dapat dilepaskan dari faktor yang menghambat yaitu subtansi hukum, struktur hukum, dan kultur hukum.

Dalam rangka penegakan hukum, hak-hak korban harus dikedepankan dan pihak terkait harus proaktif menyampaikan secara langsung kepada korban atau kepada masyarakat sehingga setiap ada korban penganiayaan yang terjadi di Kota Tidore Kepulauan dengan sendiri akan melakukan upaya hukum atau menuntut haknya, baik kepada pihak kepolisian, kejaksaan maupun kepada pihak pengadilan.

\section{KESIMPULAN}

- Implementasi perlindungan hukum terhadap korban penganiayaan di Kota Tidore Kepulauan belum optimal disamping pemahaman korban penganiayaan masih minim serta belum di dukung oleh peraturan perundang-undangan yang dapat dijadikan acuan dalam mediasi penal untuk pemberian ganti kerugian kepada korban sebagaimana dimaksud Pasal 98 KUHAP.

\section{E. SARAN}

- Dalam rancangan Kitab Hukum Acara Pidana (KUHAP) yang akan datang diharapkan ada pasal yang mengatur kewajiban Jaksa untuk mempertanyakan kepada pihak korban penganiayaan mengenai diikut sertakan tentang masalah ganti kerugian dalam dakwaan yang akan diajukan kepengadilan, juga seyogyanya semua korban penganiayaan tindak pidana khusus dan korban penganiayaan tindak pidana umum (KUHP) diberikan perlindungan yang sama.

\section{DAFTAR PUSTAKA}

Ahmad Kamil. 2012. Mediasi Penal dalam Penanganan Tindak Pidana. Mahkamah Agung Republik Indonesia : Jakarta.

Anshari Dimayanti. 2013. Kebijakan Perlindungan Hukum Terhadap Saksi dan korban. Universitas Diponegoro : Semarang.

Ansori. 2011. Perlindungan Hukum Terhadap Korban Perkosaan Dalam Peradilan Pidana di Indonesia. Disertasi : Universitas Brawijaya : Malang.

Barda Nawawi Arief. 2002. Perbadingan Hukum Pidana. PT. Raja Grafinbo Persada : Jakarta. 
2001. Masalah Penegakan Hukum Dan Kebijakan Hukum Pidana dalam Penanggulangan Kejahatan. PT. Citara Aditya Bakti : Bandung.

Bedi Setiawan Al Fahmi. 2002. Perlindungan Korban Tindak Pidana Perkosaan Dalam Proses peradilan Pidana Perspektif Pembeharuan Hukum Acara Pidana Indonesia. Jurnal Hukum dan Pembangunan No. 1 Vol. 16 Januari 2009. Badan Penerbit FH UI : Depok

Brian Z. Tamanaha. 2001. The Rule of Law Theory. Oxfory University : New York

Lies Sulistiani. 2010. Perlindungan Saksi dan Korban di Indonesia. Press Release No.02/LPSK/PR/II/2010. Lembaga Perlindungan Saksi Republik Indonesia : Jakarta.

Lili Rasjidi dan B Arief Sidharta. 1994. Filsafat Hukum Madzab dan Refleksi. Remaja Rosda Karya : Bandung.

Mardjono Reksodiputro. 2007. Kriminologi dan Sistem Peradilan Pidana (Kumpulan Karangan, Buku Kedua), Pusat Pelayanan Keadilan dan Pengabdian Hukum (d/h Lembaga Kriminologi) Universitas Indonesia : Jakarta.

Mochtar Kusumaatmadja. 2003. Pengatar Hukum Indonesia. Pusat Studi Wawasan Nusantara, Hukum dan Pembagunan bekerjasama dengan Penerbit P.T. Alumni : Bandung.

Moeljatno. 1993. Asas-asas Hukum Pidana. Rineka Cipta : Jakarta

Muchsin. 2003. Perlindungan dan Kepastian Hukum bagi Investor di Indonesia. Magister IImu Hukum Program Pascasarjana Universitas Sebelas Maret : Surakarta.

Muhadar dkk. 2010. Perlindungan Saksi dan Korban dalam Sistem Peradilan Pidana. Putera Media Nusantara : Surabaya.

Muladi. 2004. Lembaga Pidana. Bersyarat. Alumni : Bandung.

Muladi dan Arief dan Barda Nawawi Arief. 1992. Teori-teori dan Kebijakan Pidana. Alumni : Bandung.

Philipus M. Hadjon 1987. Perlindungan hukum Bagi Rakyat di Indonesia; Sebuah Studi Tentang Prinsi-prinsip, Penerapannya oleh Pengadilan Dalam Lingkungan Peradilan Umum dan Pembentukan Peradilan Administrasi Negara. Bina IImu : Surabaya.

Poerwadarminta.1998. Kamus bahasa Indonesia. Balai Pustaka : Jakarta.

Prabowo dan Dwi Riyanti. 1998. Masalah Kejiwaan Berbagai Profesi. Sinar Grafika, Jakarta

Rena Yulia. 2011. Viktimologi: Perlindungan Hukum Terhadap Korban Kejahatan. Jurnal Intelek Vulome 7 tanggal 3 Desember 2011.

Roeslan Saleh. 1984. Segi Lain Hukum Pidana. Ghalia Indonesia : Jakarta.

Soejono Soekanto. 2007. Sosiologi suatu Pengantar. PT. Raja Grafindo Persada, Jakarta

Satjipto Rahardjo. 2009. Penegakan Hukum Suatu Tinjauan Sosiologi. Genta Publishing : Jakarta.

Setiono. 2004. Rule of law (Supremasi Hukum). Magister IImu Hukum Program Pascasarjana Universitas Sebelas Maret : Surakarta.

Sholehuddin, M. 2004. Sistem Sanksi dalam Hukum Pidana. PT.Raja Grafindo Persada: Jakarta.

Sudarto. 1997. Hukum dan Hukum Pidana. Alumni. Bandung.

Sudikno. Mertokusumo. 1999. Mengenal Hukum, Suatu Pengantar. Liberty : Yogyakarta.

Wirjono Prodjodikoro. 1977. Hukum Acara Pidana di Indonesia. Sumur : Bandung

Yesmil Anwar dan Adang. 2009. Sistem Peradilan pidana Widya Pajajaran : Bandung.

Undang - Undang Dasar Negara Republik Indonesia

Undang - Undang Nomor 13 Tahun 2006 Tentang Perlindungan Saksi dan Korban

Kitab Undang - Undang Hukum Acara Pidana

www.Grafiti. Com. 10 Februari 2015 